\title{
Statistical design and optimization of single cell oil production from sugarcane bagasse hydrolysate by an oleaginous yeast Rhodotorula sp. IIP-33 using response surface methodology
}

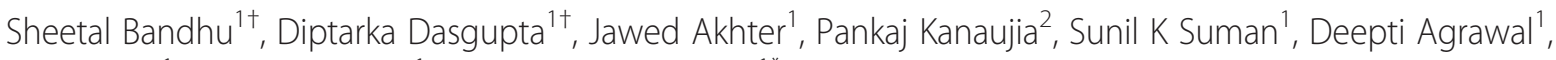 \\ Savita Kaul ${ }^{1}$, Dilip K Adhikari ${ }^{1}$ and Debashish Ghosh ${ }^{1 *}$
}

\begin{abstract}
Single cell oil production from sugarcane bagasse hydrolysate by oleaginous yeast Rhodotorula sp. IIP-33 was analyzed using a two stage statistical design approach based on Response Surface Methodology. Variables like pentose sugar, $\left(\mathrm{NH}_{4}\right)_{2} \mathrm{SO}_{4}, \mathrm{KH}_{2} \mathrm{PO}_{4}$, yeast extract, $\mathrm{pH}$ and temperature were found to influence lipid production significantly. Under optimized condition in a shake flask, yield of lipid was $2.1199 \mathrm{~g}$ with fat coefficient of 7.09 which also resembled $\sim 99 \%$ similarity to model predicted lipid production. In this paper we are presenting optimized results for production of non polar lipid which could be later deoxygenated into hydrocarbon. A qualitative analyses

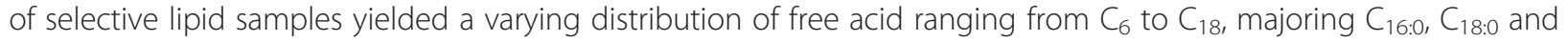
$C_{18: 1}$ under different fermentation conditions.
\end{abstract}

Keywords: Lignocellulosic biomass; Pentose sugar; Yeast lipid; Rhodotorula sp; Response surface methodology

\section{Introduction}

Plant and algae based natural fatty oils find industrial applications with continuous increasing demand as oleochemicals and biofuel feedstock. Transesterification of this lipid to its corresponding esters yield a diesel substitute which lacks in drop in' characteristics like hydrocarbon based fossil fuel (Wackett 2008). Instead, selective de-oxygenation (hydrotreatment) would yield renewable hydrocarbon of desired fuel range (gasoline, aviation jet and diesel) (Verma et al. 2011). However, plant derived lipid can hardly meet our future energy demand irrespective of transesterification or hydrotreatment. Apart from various oil seed bearing plants and microalgae, microbial lipids offer some potential advantages due to their short generation time $(80 \mathrm{~h}$ with respect to 24 months for plants or 2 months for algae); limited space requirement (could avoid food fuel debate); generation of uniform lipid

\footnotetext{
* Correspondence: dghosh@iip.res.in

${ }^{\dagger}$ Equal contributors

${ }^{1}$ Biofuels Division, CSIR-Indian Institute of Petroleum, Mohkampur, Dehradun 248005 , Uttarakhand, India

Full list of author information is available at the end of the article
}

fractions (irrespective of climate and country) ( $\mathrm{Li}$ et al. 2008). However, high processing cost still imposes a challenge for its commercialization. Maximum lipid accumulation by oleaginous microorganisms using cheap carbon sources like lignocellulosic biomass derived fermentable sugars and further recovery of single cell oil are undoubtedly major challenges for its commercial success (da Silva et al. 2014; Flores et al. 2000). Sugarcane bagasse can be a potential biomass source in terms of fermentable sugars ( $60 \%$ holocellulose content) with an average production of 350 MMT (million metric tonne) per annum. Indian sugar mills receive $40 \%$ of the total sugarcane produced. $50-55 \%$ is crushed in unorganized sector and $8-10 \%$ is utilized as seed for future crop. Normally $30 \%$ bagasse is obtained from total cane crushed in a sugar mill. Out of total bagasse generated in sugar mill, $75-85 \%$ is used to generate boiler steam and rest $15-25 \%$ is surplus for other uses mainly papermaking and co-generation. Thus Indian sugar mills generate $40-42$ MMT bagasse which can be effectively hydrolyzed and sachcharified to extract fermentable sugars for valorization to fuels or specialty chemicals instead of boiler steam generation (Jain et al. 2011). 
Oleaginous microorganisms accumulate lipid when intracellular AMP concentration declines due to depletion of culture nitrogen concentration. Hence microbial biomass generated under carbon limiting condition, channelize their carbon flux for lypogenesis during nitrogen limiting condition, in presence of high sugar density (Botham and Ratledge 1979). Flux is further driven by the reductant NADPH generated during formation of pyruvate from oxaloacetate via malate (Ratledge 2004). Temperature induced changes are reported for fatty acid and lipid quantity and composition in many oleaginous microorganisms. Rhodotorula sp. IIP-33 (hence forth mentioned as IIP-33) is one such yeast and its growth and lipid accumulation characteristics have been reported (Saxena et al. 1998).

One of the unique characteristics of IIP-33 is its ability in utilizing both pentose and hexose sugar for cell biomass generation and lipid accumulation (Chandra 1997). Cell biomass was grown with pentose rich fractions obtained after acid and steam hydrolysis of sugarcane bagasse (SCB) and nitrogen limiting conditions were obtained by adding concentrated pentose stream of SCB hydrolysate. In this paper, we have targeted quantitative accumulation (weight basis) of non polar lipid by IIP-33 by RSM (Response Surface Methodology) via two step approach. Initial screening was performed with PlackettBurman Design (PBD) (Plackett \& Burman 1946) method to identify crucial parameters affecting lipid yield and to the degree based on their individual effect and interactions through Box-Behnken Design (BBD) (Box \& Behnken 1960). Further, we had selected 13 lipid samples with varying weights from three different temperatures varying in (carbon/nitrogen) $\mathrm{C} / \mathrm{N}$ ratios for qualitative analyses of lipid through Gas chromatography coupled with mass spectroscopy (GC/MS) to find any compositional variation in terms of free fatty acids.

\section{Materials and methods Materials}

Sugar cane bagasse was procured from local sugar mill in Doiwala, Dehradun, India for hydrolysis. SCB was pretreated with steam and $4 \% \mathrm{w} / \mathrm{w} \mathrm{H}_{2} \mathrm{SO}_{4}$ in $1: 10$ solid-liquid ratio for 90 minutes holding time at $120^{\circ} \mathrm{C}$ temperature and 4 bar pressure to extract pentose rich fraction. The broth was neutralized by over-liming. Pentose sugar was used as carbon source for cell biomass generation. Pentose stream was further concentrated and used in all experimental shake flasks with desired sugar concentrations as per experimental design (Tables 1 and 2).

\section{Microorganism and culture conditions}

IIP-33 (MTCC 2518), an oleaginous yeast (GenBank Accession number KF313359) was isolated from mineral oil contaminated local soil as reported by Saxena et al. (1998). Optimally grown IIP-33 at $32^{\circ} \mathrm{C}$ and $\mathrm{pH} 4.5$ was used in this experimental study. Stock culture was maintained on YPX agar medium (composition in $\mathrm{g} / \mathrm{L}$; yeast extract, 10.0; peptone, 20.0; xylose 20.0; agar agar 20.0; $\mathrm{pH}$ 4.5-5.0.

\section{Experimental design}

Biomass generation was carried out in SCB hydrolysate (20 g.L $\left.\mathrm{L}^{-1}\right)$ with peptone $\left(20\right.$ g.L $\left.\mathrm{L}^{-1}\right)$ and yeast extract $\left(10{\mathrm{~g} . \mathrm{L}^{-1}}^{\text {) }}\right.$ in $10 \mathrm{~L}$ fermenter (INCELTECH LH Series 210 fermenter, Berkshire, England) at $32^{\circ} \mathrm{C}$. Growth was terminated after $90 \%$ consumption of sugar which was nearly $12 \mathrm{~h}$ from the onset of inoculation. Nutrient screening and optimization for lipid production with

Table 1 Plackett burman design for initial screening of factors

\begin{tabular}{|c|c|c|c|c|c|c|c|c|c|c|c|c|}
\hline \multirow{2}{*}{$\begin{array}{l}\text { Run } \\
\text { order }\end{array}$} & \multirow{2}{*}{$\begin{array}{l}\text { Std. } \\
\text { order }\end{array}$} & \multirow{2}{*}{$\begin{array}{c}\text { A } \\
\text { Xylose } \\
\mathbf{g} \\
\end{array}$} & \multirow{2}{*}{$\begin{array}{c}\text { B } \\
\left(\mathrm{NH}_{4}\right)_{2} \mathrm{SO}_{4} \\
\mathrm{~g} \\
\end{array}$} & \multirow{2}{*}{$\begin{array}{c}\mathrm{C} \\
\mathrm{Na}_{2} \mathrm{HPO}_{4} \\
\mathrm{~g}\end{array}$} & \multirow{2}{*}{$\begin{array}{c}\text { D } \\
\mathrm{KH}_{2} \mathrm{PO}_{4} \\
\mathrm{~g} \\
\end{array}$} & \multirow{2}{*}{$\begin{array}{c}\text { E } \\
\text { Yeast extract } \\
\text { g } \\
\end{array}$} & \multirow{2}{*}{$\begin{array}{c}\mathrm{F} \\
\mathrm{MgSO}_{4} \\
\mathrm{~g} \\
\end{array}$} & \multirow{2}{*}{$\begin{array}{c}\mathbf{G} \\
\text { Time } \\
\mathbf{h} \\
\end{array}$} & \multirow{2}{*}{$\begin{array}{c}\mathrm{H} \\
\mathrm{pH} \\
-\end{array}$} & \multirow{2}{*}{$\begin{array}{c}\text { I } \\
\text { Temp } \\
{ }^{\circ} \mathrm{C} \\
\end{array}$} & \multicolumn{2}{|c|}{ Response variable: Lipid wt. } \\
\hline & & & & & & & & & & & $\begin{array}{c}\text { Experimental } \\
\mathbf{g}\end{array}$ & $\begin{array}{c}\text { Predicted } \\
\mathbf{g} \\
\end{array}$ \\
\hline 1 & 7 & +1 & -1 & -1 & -1 & +1 & -1 & +1 & +1 & -1 & 1.4363 & 1.4482 \\
\hline 2 & 8 & +1 & +1 & -1 & -1 & -1 & +1 & -1 & +1 & +1 & 1.0892 & 1.089 \\
\hline 3 & 9 & +1 & +1 & +1 & -1 & -1 & -1 & +1 & -1 & +1 & 0.7101 & 0.710 \\
\hline 5 & 10 & -1 & +1 & +1 & +1 & -1 & -1 & -1 & +1 & -1 & 1.3764 & 1.3883 \\
\hline 6 & 6 & -1 & -1 & -1 & +1 & -1 & +1 & +1 & -1 & +1 & 1.7299 & 1.7418 \\
\hline 7 & 1 & +1 & +1 & -1 & +1 & +1 & +1 & -1 & -1 & -1 & 0.5932 & 0.5932 \\
\hline 8 & 5 & -1 & -1 & +1 & -1 & +1 & +1 & -1 & +1 & +1 & 1.0931 & 1.0931 \\
\hline 9 & 4 & -1 & +1 & -1 & +1 & +1 & -1 & +1 & +1 & +1 & 1.4091 & 1.3972 \\
\hline 10 & 3 & +1 & -1 & +1 & +1 & -1 & +1 & +1 & +1 & -1 & 2.6138 & 2.6019 \\
\hline 11 & 12 & -1 & -1 & -1 & -1 & -1 & -1 & -1 & -1 & -1 & 0.5911 & 0.5792 \\
\hline 12 & 11 & +1 & -1 & +1 & +1 & +1 & -1 & -1 & -1 & +1 & 1.8509 & 1.8509 \\
\hline
\end{tabular}


Table 2 Box Behnken design for lipid production

\begin{tabular}{|c|c|c|c|c|c|c|c|c|c|}
\hline $\begin{array}{l}\text { Std } \\
\text { order }\end{array}$ & $\begin{array}{l}\text { Run } \\
\text { order }\end{array}$ & $\begin{array}{c}\text { A } \\
\text { Xylose }\end{array}$ & $\begin{array}{c}\text { B } \\
\left(\mathrm{NH}_{4}\right)_{2} \mathrm{SO}_{4}\end{array}$ & $\begin{array}{c}\mathrm{C} \\
\mathrm{KH}_{2} \mathrm{PO}_{4}\end{array}$ & $\begin{array}{c}\text { D } \\
\text { Yeast extract }\end{array}$ & $\begin{array}{c}\mathrm{E} \\
\mathrm{pH}\end{array}$ & $\begin{array}{c}\mathrm{F} \\
\text { Temperature }\end{array}$ & $\begin{array}{l}\text { Lipid } \\
\text { weight }\end{array}$ & $\begin{array}{l}\text { Model } \\
\text { predicted } \\
\text { response }\end{array}$ \\
\hline & & g & g & g & g & - & ${ }^{\circ} \mathrm{C}$ & g & g \\
\hline 32 & 1 & 0 & -1 & 0 & 0 & +1 & -1 & 1.492 & 1.4913 \\
\hline 45 & 2 & -1 & 0 & -1 & 0 & 0 & -1 & 0.776 & 0.779 \\
\hline 42 & 3 & 0 & +1 & 0 & 0 & -1 & -1 & 1.177 & 1.1767 \\
\hline 10 & 4 & 0 & 0 & +1 & +1 & 0 & -1 & 1.465 & 1.4742 \\
\hline 17 & 5 & 0 & -1 & 0 & 0 & -1 & -1 & 1.253 & 1.252 \\
\hline 24 & 6 & 0 & 0 & -1 & -1 & 0 & -1 & 1.206 & 1.205 \\
\hline 25 & 7 & 0 & 0 & -1 & +1 & 0 & -1 & 1.326 & 1.3231 \\
\hline 12 & 8 & +1 & 0 & -1 & 0 & 0 & -1 & 1.752 & 1.7539 \\
\hline 38 & 9 & 0 & 0 & +1 & -1 & 0 & -1 & 1.364 & 1.3654 \\
\hline 9 & 10 & 0 & +1 & 0 & 0 & +1 & -1 & 1.410 & 1.4097 \\
\hline 27 & 11 & 1 & 0 & +1 & 0 & 0 & -1 & 1.972 & 1.9689 \\
\hline 6 & 12 & -1 & 0 & +1 & 0 & 0 & -1 & 0.878 & 0.8754 \\
\hline 4 & 13 & 0 & -1 & -1 & 0 & -1 & 0 & 1.226 & 1,2276 \\
\hline 20 & 14 & 0 & +1 & +1 & 0 & +1 & 0 & 1.545 & 1.5445 \\
\hline 28 & 15 & +1 & +1 & 0 & +1 & 0 & 0 & 1.938 & 1.9378 \\
\hline 1 & 16 & -1 & -1 & 0 & -1 & 0 & 0 & 0.844 & 0.8457 \\
\hline 14 & 17 & +1 & -1 & 0 & -1 & 0 & 0 & 1.872 & 1.8731 \\
\hline 44 & 18 & -1 & 0 & 0 & -1 & +1 & 0 & 0.868 & 0.8691 \\
\hline 36 & 19 & 0 & +1 & -1 & 0 & +1 & 0 & 1.380 & 1.381 \\
\hline 39 & 20 & -1 & 0 & 0 & +1 & -1 & 0 & 0.892 & 0.8917 \\
\hline 35 & 21 & 0 & +1 & -1 & 0 & -1 & 0 & 1.153 & 1.1542 \\
\hline 34 & 22 & +1 & 0 & 0 & -1 & -1 & 0 & 1.683 & 1.6848 \\
\hline 37 & 23 & -1 & +1 & 0 & -1 & 0 & 0 & 0.746 & 0.7466 \\
\hline 16 & 24 & +1 & 0 & 0 & +1 & +1 & 0 & 2.09 & 2.065 \\
\hline 18 & 25 & -1 & 0 & 0 & -1 & -1 & 0 & 0.741 & 0.742 \\
\hline 31 & 26 & -1 & +1 & 0 & +1 & 0 & 0 & 0.899 & 0.8989 \\
\hline 26 & 27 & +1 & 0 & 0 & -1 & +1 & 0 & 2.024 & 2.0251 \\
\hline 43 & 28 & 0 & -1 & -1 & 0 & +1 & 0 & 1.459 & 1.4607 \\
\hline 52 & 29 & 0 & +1 & +1 & 0 & -1 & 0 & 1.307 & 1.3061 \\
\hline 7 & 30 & 0 & -1 & +1 & 0 & -1 & 0 & 1.380 & 1.3795 \\
\hline 30 & 31 & +1 & -1 & 0 & +1 & 0 & 0 & 1.992 & 1.9918 \\
\hline 3 & 32 & 0 & -1 & +1 & 0 & 1 & 0 & 1.624 & 1.6243 \\
\hline 29 & 33 & +1 & +1 & 0 & -1 & 0 & 0 & 1.817 & 1.818 \\
\hline 5 & 34 & -1 & 0 & 0 & +1 & +1 & 0 & 1.023 & 1.0229 \\
\hline 13 & 35 & -1 & -1 & 0 & +1 & 0 & 0 & 0.997 & 0.9969 \\
\hline 41 & 36 & +1 & 0 & 0 & +1 & -1 & 0 & 1.802 & 1.8019 \\
\hline 40 & 37 & 0 & +1 & 0 & 0 & +1 & +1 & 1.514 & 1.5157 \\
\hline 11 & 38 & +1 & 0 & +1 & 0 & 0 & +1 & 2.0743 & 2.0744 \\
\hline 2 & 39 & -1 & 0 & +1 & 0 & 0 & +1 & 0.981 & 0.9829 \\
\hline 21 & 40 & 0 & +1 & 0 & 0 & -1 & +1 & 1.282 & 1.2834 \\
\hline 8 & 41 & -1 & 0 & -1 & 0 & 0 & +1 & 0.882 & 0.8825 \\
\hline 19 & 42 & 0 & 0 & -1 & -1 & 0 & +1 & 1.291 & 1.2855 \\
\hline
\end{tabular}


Table 2 Box Behnken design for lipid production (Continued)

\begin{tabular}{llcccccccc}
\hline 46 & 43 & 0 & -1 & 0 & 0 & +1 & +1 & 1.593 & 1.5935 \\
22 & 44 & 0 & 0 & +1 & +1 & 0 & +1 & 1.604 & 1.6027 \\
15 & 45 & +1 & 0 & -1 & 0 & 0 & +1 & 1.854 & 1.8554 \\
23 & 46 & 0 & 0 & -1 & +1 & 0 & +1 & 1.445 & 1.4476 \\
33 & 47 & 0 & -1 & 0 & 0 & -1 & +1 & 1.354 \\
\hline
\end{tabular}

generated biomass were performed in shake flasks $(0.5 \mathrm{~L}$ working volume; $20 \mathrm{~g}$ cell on dry basis) in biomass hydrolysate with various nutrients according to experimental design. Physical parameters, temperature, $\mathrm{pH}$ and fermentation time were maintained as per experimental design (Table 1). Experiments were carried out in duplicate sets and final data were reported in terms of mean values. Experimental design and statistical analysis were performed with Reliasoft Design of Experiment (DOE) software with a risk factor $(\alpha)$ of 0.05 (i.e. $95 \%$ level of confidence) for both PBD and BBD. Coefficient of regression $\left(\mathrm{R}^{2} \mathrm{adj}\right)$ with value over 0.98 was selected as criterion for acceptance of predicted model. Variables with $\mathrm{P}$ values lower than 0.05 were considered to have a significant effect on lipid production.

\section{Plackett Burman design for initial screening}

A two level PBD experimental matrix was set up to identify factors and estimate their significance in lipid production by IIP-33. A total of nine independent variables were selected for this study; physical parameters such as temperature, $\mathrm{pH}$, fermentation time and media components such as xylose concentration, ammonium sulphate $\left[\left(\mathrm{NH}_{4}\right)_{2} \mathrm{SO}_{4}\right]$, disodium hydrogen phosphate $\left[\mathrm{Na}_{2} \mathrm{HPO}_{4}\right]$ and potassium di-hydrogen phosphate $\left[\mathrm{KH}_{2} \mathrm{PO}_{4}\right]$, yeast extract and magnesium sulphate $\left[\mathrm{MgSO}_{4}\right]$. Each variable was represented at three levels, low (-1), medium (0) and high (1) concentration (Table 3). According to PBD, eleven trials were performed with lipid content $(Y)$ as

Table 3 Variables with their coded levels

\begin{tabular}{ccccc}
\hline Serial number & Variables & $\begin{array}{c}\text { Low } \\
(\mathbf{- 1})\end{array}$ & $\begin{array}{c}\text { Medium } \\
\mathbf{( 0 )}\end{array}$ & $\begin{array}{c}\text { High } \\
\mathbf{( + 1 )}\end{array}$ \\
\hline 1 & Xylose $(\mathrm{g})$ & 10 & 20 & 30 \\
2 & $\left(\mathrm{NH}_{4}\right)_{2} \mathrm{SO}_{4}(\mathrm{~g})$ & 0.5 & 0.75 & 1 \\
3 & $\mathrm{Na}_{2} \mathrm{HPO}_{4}(\mathrm{~g})$ & 0.188 & 0.2815 & 0.375 \\
4 & $\left(\mathrm{KH}_{2} \mathrm{PO}_{4}\right)(\mathrm{g})$ & 0.35 & 0.525 & 0.70 \\
5 & $\mathrm{Yeast} \mathrm{extract}(\mathrm{g})$ & 0.25 & 0.50 & 0.75 \\
6 & $\mathrm{MgSO}_{4}(\mathrm{~g})$ & 0.175 & 0.3375 & 0.50 \\
7 & $\mathrm{Time}(\mathrm{h})_{8}$ & 18 & 24 & 30 \\
9 & $\mathrm{pH}$ & 4 & 5 & 6 \\
\hline
\end{tabular}

response (Table 1). Final predicted model was linear, with only main effects in consideration.

$$
\text { Response }=\mathrm{a}+\sum \mathrm{b}_{\mathrm{i}} \mathrm{X}_{\mathrm{i}}
$$

Response indicated dependent variable in terms of overall lipid production (g. $\mathrm{L}^{-1}$ ), a being model intercept. $\mathrm{X}_{\mathrm{i}}$ represented different levels of independent variables with $b_{i}$ coefficients as predicted by the Equation 1 .

\section{BBD design for lipid optimization}

Following Placket Burman screening of factors, BBD was applied to further develop mathematical correlations between key independent variables on lipid production. $\mathrm{BBD}$ matrix was constructed with six significant factors (xylose concentration, $\left(\mathrm{NH}_{4}\right)_{2} \mathrm{SO}_{4}, \mathrm{KH}_{2} \mathrm{PO}_{4}$, yeast extract, $\mathrm{pH}$ and temperature) each having 3 levels $(-1,0$ and 1$)$ with 47 experimental designs as shown in Table 2. All non-significant factors predicted by PBD like time, $\mathrm{MgSO}_{4}$ and $\mathrm{Na}_{2} \mathrm{HPO}_{4}$, were kept at their respective low level values (Table 3). BBD response was fit by a second-order polynomial in order to correlate response with independent factors. ANOVA analysis of predicted model was carried out to evaluate its statistical significance. System response predicted by second order polynomial was represented as a combination of linear, interaction and quadratic effect of independent variables on system response, either + ve or -ve.

$$
\text { Response }=\beta_{0}+\Sigma \beta_{\mathrm{i}} \mathrm{x}_{\mathrm{i}}+\Sigma \beta_{\mathrm{ij}} \mathrm{x}_{\mathrm{ij}}+\Sigma \beta_{\mathrm{ii}} \mathrm{x}_{\mathrm{i}}^{2}
$$

Where, $x_{i}$ represented independent variables, $\beta_{0}$ was intercept, $\beta_{\mathrm{i}}$, linear term coefficients, $\beta_{\mathrm{ij}}$ indicated interaction terms and $\beta_{\mathrm{ii}}$ represented quadratic effect terms.

\section{Model validation in shake flask}

BBD study predicted optimized condition for lipid production in terms of key independent variables having significant impact on lipid production. A shake flask study under optimized condition was performed to validate correctness of the predicted computational model.

\section{Qualitative estimation of lipid for selected samples}

Amongst 47 software predicted experimental sets 12 lipid samples were selected for qualitative distribution of fatty acid in terms of carbon numbers through GC/MS. Samples were selected on the basis of maximum quantitative 
lipid yield under three different temperatures with varying $\mathrm{C} / \mathrm{N}$ ratio, temperature and $\mathrm{pH}$ for lipid fermentation and relative fatty acids distribution was tabulated (Table 4). Finally, this was also compared with the lipid generated in model validated flask.

\section{Estimation of lipid and analytical methods}

After fermentation, cells were separated by centrifugation and dried. Lipid was extracted from dry cell biomass in two stage solvent extraction method. In first stage, total lipids were extracted with 1:3 chloroform/ methanol $\left(\mathrm{CHCl}_{3}: \mathrm{CH}_{3} \mathrm{OH}\right)$ and then followed by $\mathrm{n}$ hexane. Solvents were evaporated under vacuum to collect and quantify lipid on weight basis. Estimation of sugar (xylose in prehydrolysate) during cell biomass generation and lipid maturation was quantified by High pressure liquid chromatography (HPLC) (UFLC, Shimadzu, Japan) with PL Hiplex-H acid $8 \mu \mathrm{m}$ column $(100 \times 7.7 \mathrm{~mm}$ diameter, by PL Polymer laboratory, UK). Column was eluted with a mobile phase $1 \mathrm{mM}$ sulfuric acid at a flow rate of $0.7 \mathrm{ml} \cdot \mathrm{min}^{-1}$ at column oven temperature $70^{\circ} \mathrm{C}$ with refractive Index (RI) detector. Total nitrogen was analyzed by UV method as per ASTM D 4629 with Total Nitrogen Analyzer (TN3000, Thermo-Fischer). Known quantity of cellular broth $(1 \mathrm{ml})$ was used for determination of dry cell weight (DCW) by hot air drying of cell pellets in microfuges. Average of triplicate data was considered for DCW determination. Qualitative gas GC/MS analyses were performed with a Hewlett Packard 5890 gas chromatograph equipped with a model 5972 mass selective detector (Hewlett Packard, USA). A SGE BPX5 capillary column with $30 \mathrm{~m}$ length $\times 0.25 \mathrm{~mm}$ internal diameter $\times 0.32 \mu \mathrm{m}$ film thickness was used. GC oven temperature was programmed from $50^{\circ} \mathrm{C}$ (hold for $2 \mathrm{~min}$ ) to a final temperature of $300^{\circ} \mathrm{C}$ at $10^{\circ} \mathrm{C} \cdot \mathrm{min}^{-1}$ (hold for $30 \mathrm{~min}$ ). Helium was used as a carrier gas under constant flow $\left(1.2 \mathrm{ml} \cdot \mathrm{min}^{-1}\right)$ mode. Transfer line temperature was fixed to $280^{\circ} \mathrm{C}$. All samples were analyzed in splitless mode at an injection temperature of $250^{\circ} \mathrm{C} .1 \mu \mathrm{L}$ injection of samples was performed with a $5 \mu \mathrm{L}$ micro syringe. Mass spectrometric analyses were carried out in electron ionization (EI) mode with $70 \mathrm{eV}$ ionization energy and $150^{\circ} \mathrm{C}$ quadruple temperature. Ion source temperature was kept at $230^{\circ} \mathrm{C}$. Mass spectra for all target compounds were acquired in full scan mode after derivatization with BSTFA (N, O-bis-trimethylsilyl trifluoroacetamide, Sigma Aldrich, India). Derivatization was performed by taking $50 \mu \mathrm{L}$ analyte solutions in hexane (approximate concentration of $1 \mathrm{mg} \cdot \mathrm{ml}^{-1}$ ) and adding $100 \mu \mathrm{L}$ of BSTFA in a glass vial with screw cap and Teflon seal. This vial was kept at $80^{\circ} \mathrm{C}$ for 1 hour and injected in GC/MS.

\section{Results and discussion}

\section{Screening of key variables affecting lipid production}

Optimum microbial lipid production required a perfect association of micro and macro nutrients such as carbon and nitrogen along with other physical parameters namely temperature and $\mathrm{pH}$ whereby a suitable environment was provided for yeast growth and proliferation. A medium with excess pentose sugar in the form of SCB hydrolysate and limited nitrogen content greatly enhanced lipid production. Oleaginous profile was significantly affected by

Table 4 Relative fatty acid of 13 selective lipid samples

\begin{tabular}{|c|c|c|c|c|c|c|c|c|c|c|c|c|c|c|}
\hline & & & & & & $C_{5}$ sugar $^{\delta}$ & Fat coefficient $^{\Psi}$ & $\leq C_{6}$ to $\geq C_{14}$ & $C_{16: 0}$ & $C_{16: 1}$ & $C_{18: 0}$ & $C_{18: 1}$ & $C_{18: 2}$ & $C_{18: 3}$ \\
\hline$\#$ & ${ }^{\circ} \mathrm{C}$ & $\sim$ & g & - & $\#$ & g & $\%$ & relative pr & $\begin{array}{r}\text { esence } \\
c\end{array}$ & $\begin{array}{l}\text { of fatty } \\
\text { arbon n }\end{array}$ & $\begin{array}{l}\text { acids } \\
\text { umber }\end{array}$ & of corre & spondi & \\
\hline 1 & 30 & 25 & 0.8780 & 5 & 12 & 10 & 8.78 & ++ & + & - & + & + & - & + \\
\hline 2 & 30 & 50 & 1.4650 & 5 & 4 & 20 & 7.33 & + & ++ & + & + & + & - & + \\
\hline 3 & 30 & 75 & 1.9720 & 5 & 11 & 30 & 6.57 & ++ & ++ & + & + & ++ & - & + \\
\hline 4 & 34 & 25 & 0.8990 & 5 & 26 & 10 & 8.99 & + & + & - & - & + & + & - \\
\hline 5 & 34 & 50 & 1.9380 & 5 & 15 & 30 & 6.46 & + & ++ & + & + & ++ & ++ & - \\
\hline 6 & 34 & 75 & 2.0243 & 6 & 27 & 10 & $20.24^{n}$ & + & ++ & + & ++ & ++ & ++ & - \\
\hline 7 & 34 & 75 & 2.0900 & 6 & 24 & 30 & 6.96 & ++ & ++ & + & ++ & ++ & ++ & - \\
\hline 8 & 34 & 100 & 1.8720 & 5 & 17 & 30 & 6.24 & + & ++ & - & ++ & ++ & ++ & - \\
\hline 9 & 34 & 100 & 1.9920 & 5 & 31 & 30 & 6.64 & + & ++ & + & ++ & ++ & ++ & - \\
\hline 10 & 38 & 25 & 0.8820 & 5 & 42 & 10 & 8.82 & ++ & + & + & + & + & + & - \\
\hline 11 & 38 & 50 & 1.5140 & 6 & 38 & 20 & 7.57 & + & + & + & + & + & ++ & - \\
\hline 12 & 38 & 75 & 2.0740 & 5 & 39 & 30 & 6.91 & ++ & ++ & - & + & ++ & ++ & - \\
\hline 13 & 38 & 100 & 2.1199 & 6 & model & 30 & $7.06^{*}$ & ++ & ++ & + & ++ & ++ & ++ & - \\
\hline
\end{tabular}

+ indicates presence of fatty acids with corresponding carbon numbers as per GC/MS; ++ indicates presence of corresponding fatty acids in higher quantity as per GC/MS; $\delta$ gram of pentose sugar $\left(C_{5}\right)$ present in prehydrolysate as carbon source in all flasks; $\psi$ (yielded lipid/consumed sugar) $\times 100=$ fat coefficient $(\%)$; $\eta$ maximum fat coefficient due to low carbon content and high $\mathrm{C} / \mathrm{N}$ ratio (very low nitrogen content); not considered as model data; * fat coefficient as per validated model. 
$\mathrm{C} / \mathrm{N}$ molar ratio of the culture (Ratledge and Wynn 2002) with higher values $(\mathrm{C} / \mathrm{N} 50)$ of the same being more favourable for lipid production (Braunwald et al. 2013). However, this resulted in reduced biomass yield and specific growth rate of IIP-33. Temperature played a significant role in determining lipid quality of the yeast. Slight variation in temperature altered fatty acid composition of the lipids. As culture temperature increased, relative content of unsaturated fatty acids in cellular lipids increased (Hamid and Khan 1991; Amaretti et al. 2010). This is attributed to better cellular adaptation at those temperatures. Thus by fine tuning temperature, lipid quality could be significantly altered. Inorganic salts such as $\mathrm{Na}_{2} \mathrm{HPO}_{4}$ and $\mathrm{KH}_{2} \mathrm{PO}_{4}$ acted as buffering agents and helped to maintain cell integrity during growth and also played a significant role in phospholipid accumulation. Magnesium ions were important cofactors and its enhanced levels had significant influence on cell growth and lipid accumulation. Yeast extract was a rich source of vitamins and promoted cell growth and proliferation (Dasgupta et al. 2013). Elevated levels of magnesium enhanced accumulation of lipid by promoting acetyl CoA carboxylase enzyme activity (Janßen et al. 2013). pH primarily affected lipid content and lipid quality. Lipid content generally increased when $\mathrm{pH}$ is kept at higher than optimal. Low $\mathrm{pH}$ resulted in accumulation of higher saturated fatty acids which reducd membrane fluidity.
Microbial lipid production by oleaginous yeast was quantified in terms of both total lipid content and lipid coefficient (Holdsworth and Ratledge 1988). Lipid content referred to production yield, whereas lipid coefficient was related to its efficiency of bioconversion from substrate to lipid. Table 1 summarized lipid contents obtained from Plackett-Burman experimental design for 11 trials with two levels of concentration for each independent variable. Pareto chart analysis (Figure 1) identified key variables for lipid production based on PBD experimental study. 6 factors among selected ones such as $\mathrm{KH}_{2} \mathrm{PO}_{4},(\mathrm{NH} 4)_{2} \mathrm{SO}_{4}, \mathrm{pH}$, Xylose concentration, Yeast extract and temperature with $\mathrm{T}$ values above threshold (12.706 in this study) and $P$ values lower than 0.05 were found to have a significant effect on the system response. Regression data table analysis for PBD (Table 5) highlighted that the components $\mathrm{MgSO}_{4}$, fermentation time and $\mathrm{Na}_{2} \mathrm{HPO}_{4}$ had no significant effect on system response as their $\mathrm{P}$ values were above the selected criteria for $95 \%$ level of confidence. Positive sign (+) for the effective component suggested that, further optimization preferred a similar or higher value than indicated one, and vice versa. The model considering variable main effects was highly accurate with $R_{\text {adj }}^{2}$ value of 0.99 with experimental and model predicted responses was near identical. 6 independent variables having significant effect on system response were further evaluated using BBD with 3 levels

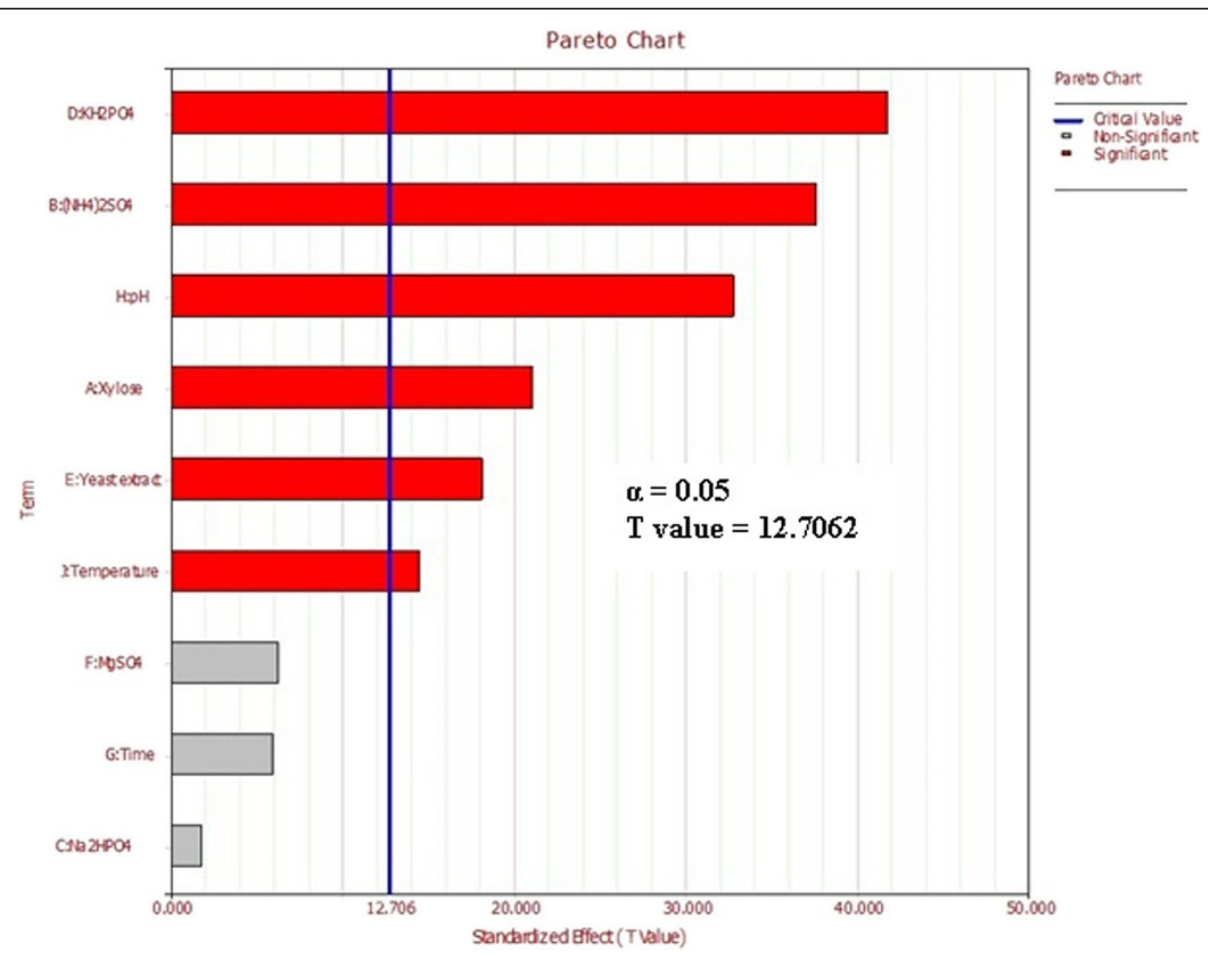

Figure 1 Pareto chart for Placket Burman screening of variables. 
Table 5 Regression analysis for PBD

\begin{tabular}{|c|c|c|c|c|c|}
\hline Term & Effect & Coefficient & Standard Error & T Value & P Value \\
\hline Intercept & & 2.2278 & 0.051 & 43.7165 & 0.0146 \\
\hline A:Xylose & 0.4396 & 0.2198 & 0.0103 & 21.328 & 0.0298 \\
\hline $\mathrm{B}:\left(\mathrm{NH}_{4}\right)_{2} \mathrm{SO}_{4}$ & -0.7801 & -0.3901 & 0.0103 & -37.85 & 0.0168 \\
\hline $\mathrm{C}: \mathrm{Na}_{2} \mathrm{HPO}_{4}$ & 0.0842 & 0.0421 & 0.0207 & 2.0361 & 0.2906 \\
\hline $\mathrm{D}: \mathrm{KH}_{2} \mathrm{PO}_{4}$ & 1.7324 & 0.8662 & 0.0206 & 42.0253 & 0.0151 \\
\hline E:Yeast extract & -0.7572 & -0.3786 & 0.0206 & -18.369 & 0.0346 \\
\hline F:MgSO 4 & -0.2661 & -0.1331 & 0.0206 & -6.456 & 0.0978 \\
\hline G:Time & 0.1269 & 0.0635 & 0.0103 & 6.1584 & 0.1025 \\
\hline $\mathrm{H}: \mathrm{pH}$ & 0.6811 & 0.3405 & 0.0103 & 33.0432 & 0.0193 \\
\hline J:Temperature & 0.3025 & 0.1513 & 0.0103 & 14.678 & 0.0433 \\
\hline
\end{tabular}

*Significant variables have been indicated in bold.

of variation while rest non-significant factors were kept at their lowermost values.

Optimization of medium components and physical factors by Box-Behnken factorial design

Lipid production via BBD matrix is shown in Table 2. ANOVA calculations illustrated in Table 6 depicted that the model $\mathrm{F}$ and $\mathrm{P}$ values were $2.61 \times 10^{4}$ and $2.93 \times 10^{-40}$. Hence model was significant with $95 \%$ level of confidence with linear, interaction and exhibited quadratic effects. Coefficient of determination of the predicted model $\left(\mathrm{R}_{\mathrm{adj}} 2\right)$ was calculated as 0.99 . Statistical equation was unable to explain only $1 \%$ variability in the response data. Response values obtained with individual runs were near identical to model predicted data values. This indicated a good agreement between experimental and predicted values for lipid content (Table 7). T-value measured how large a coefficient was in relationship to its standard error (i.e. a 'signal-to-noise' type). It was observed that main effects were significant for each of the six coded factors whereas interactions among xylose and $\left(\mathrm{NH}_{4}\right)_{2} \mathrm{SO}_{4}$, xylose and $\mathrm{KH}_{2} \mathrm{PO}_{4}$, xylose and $\mathrm{pH}$, yeast extract and temperature etc. were important as indicated by their high $\mathrm{T}$ and low $\mathrm{P}$ values. The final response i.e. lipid content modelled as a function of independent variables in terms of their coded values with both main and interaction affected in consideration has been shown below as:

$$
\begin{aligned}
& \text { Response }=1.3661+0.5166 * A-0.0383 * B+ \\
& 0.0789 * C-0.0181 * D+0.1179 * \\
& E+0.0522 * F+0.011 * A * B+ \\
& 0.0297 * A * C-0.0081 * A * D+ \\
& 0.0533 * A * E+0.0029 * C * E+ \\
& 0.011 * D * F+0.0124 * A * A+ \\
& 0.0090 * C * C+0.01 * D * D+ \\
& 0.0095 * E * E+0.0090 * F * F
\end{aligned}
$$

3D response surface graphs displayed characteristic effects of key process variables on lipid production. Figure 2 represented response against Xylose and $\left(\mathrm{NH}_{4}\right)$ ${ }_{2} \mathrm{SO}_{4}$ conc. while rest of the variables $\mathrm{KH}_{2} \mathrm{PO}_{4}$, Yeast ex-

\begin{tabular}{|c|c|c|c|c|c|}
\hline Source of Variation & Degrees of freedom & Sum of squares [Partial] & Mean Squares [Partial] & F Ratio & P Value \\
\hline Model & 27 & 7.1309 & 0.2641 & $2.61 E+04$ & $2.93 \mathrm{E}-40$ \\
\hline Linear Effects & 6 & 7.091 & 1.1818 & 1.17E + 05 & 2.37E-44 \\
\hline Interaction Effects & 15 & 0.0329 & 0.0022 & 216.6106 & 8.93E-19 \\
\hline Quadratic Effects & 6 & 0.0047 & 0.0008 & 77.903 & $8.28 \mathrm{E}-13$ \\
\hline Residual & 20 & 0.0002 & $1.01 \mathrm{E}-05$ & & \\
\hline Lack of Fit & 20 & 0.0002 & $1.01 \mathrm{E}-05$ & & \\
\hline Total & 47 & 7.1311 & & & \\
\hline
\end{tabular}
tract, $\mathrm{pH}$ and Temperature were held constant at their centre point values $(0,0,0,0)$ i.e. $0.525 \mathrm{~g}, 0.5 \mathrm{~g}, 5$ and 34 respectively. Linear surface exhibited a greater first degree effect of both independent variables on system response. An increase in sugar concentration and decrease of $\left(\mathrm{NH}_{4}\right)_{2} \mathrm{SO}_{4}$ led to enhanced lipid production, the

Table 6 ANOVA data table for BBD

*Significant model effects have been indicated in bold. 
Table 7 Significance of term coefficients for BBD

\begin{tabular}{|c|c|c|c|c|}
\hline Term & Coefficient & Standard error & $\mathrm{T}$ value & $P$ value \\
\hline Intercept & 1.3661 & 0.0026 & 517.7999 & 2.73E-07 \\
\hline A:Xylose & 0.5166 & 0.0006 & 795.4539 & $1.78 \mathrm{E}-15$ \\
\hline $\mathrm{B}:\left(\mathrm{NH}_{4}\right)_{2} \mathrm{SO}_{4}$ & -0.0383 & 0.0006 & -58.9734 & 0.0011 \\
\hline $\mathrm{C}: \mathrm{KH}_{2} \mathrm{PO}_{4}$ & 0.0789 & 0.0007 & 116.0206 & 1.37E-05 \\
\hline D:Yeast extract & -0.0181 & 0.0007 & 99.6837 & 0.0477 \\
\hline E:pH & 0.1179 & 0.0006 & 181.5286 & $1.16 \mathrm{E}-06$ \\
\hline F:Temperature & 0.0522 & 0.0007 & 76.8728 & 3.53E-07 \\
\hline$A B$ & 0.011 & 0.0011 & 9.7794 & 4.60E-09 \\
\hline$A C$ & 0.0297 & 0.0011 & 26.3607 & 0 \\
\hline$A D$ & -0.0081 & 0.0008 & -10.2154 & $2.21 \mathrm{E}-09$ \\
\hline $\mathrm{AE}$ & 0.0533 & 0.0011 & 47.4151 & 0 \\
\hline$A F$ & $-5.00 \mathrm{E}-04$ & $1.10 \mathrm{E}-03$ & -0.451 & 0.6568 \\
\hline$B C$ & 0 & 0.0011 & 0 & 1 \\
\hline $\mathrm{BD}$ & 0.0003 & 0.0011 & 0.2355 & 0.8162 \\
\hline $\mathrm{BE}$ & -0.0016 & 0.0008 & -1.9723 & 0.0626 \\
\hline $\mathrm{BF}$ & $9.00 \mathrm{E}-04$ & 1.10E-03 & 0.8353 & 0.4134 \\
\hline$C D$ & -0.0023 & 0.0013 & -1.8153 & 0.0845 \\
\hline CE & 0.0029 & 0.0011 & 2.593 & 0.0174 \\
\hline CF & 1.00E-03 & $9.00 \mathrm{E}-04$ & 1.1744 & 0.254 \\
\hline $\mathrm{DE}$ & 0.001 & 0.0011 & 0.9209 & 0.3681 \\
\hline DF & 0.011 & $1.30 \mathrm{E}-03$ & 8.6233 & $3.59 \mathrm{E}-08$ \\
\hline EF & $-2.00 \mathrm{E}-04$ & 1.10E-03 & -0.1742 & 0.8634 \\
\hline AA & 0.0124 & 0.0013 & 9.2964 & $1.06 \mathrm{E}-08$ \\
\hline BB & $8.72 \mathrm{E}-05$ & 0.0014 & 0.0637 & 9.50E-01 \\
\hline CC & 0.009 & 0.0015 & 5.9536 & 8.02E-06 \\
\hline DD & 0.01 & 0.0013 & 7.6217 & $2.44 \mathrm{E}-07$ \\
\hline $\mathrm{EE}$ & $9.50 \mathrm{E}-03$ & 1.10E-03 & 8.2952 & $6.63 \mathrm{E}-08$ \\
\hline $\mathrm{FF}$ & $9.00 \mathrm{E}-03$ & $6.00 \mathrm{E}-04$ & 15.4471 & $1.40 \mathrm{E}-12$ \\
\hline
\end{tabular}

*Significant variables have been indicated in bold.

maximum being $1.9315 \mathrm{~g}$ at $30 \mathrm{~g}$ of the former and $0.5 \mathrm{~g}$ of the latter. Thus, increase in $\mathrm{C} / \mathrm{N}$ ratio had a positive effect on system response which was also reported by Wiebe et al. (2012). Figure 3 depicted effect of $\mathrm{pH}$ and $\left(\mathrm{NH}_{4}\right)$ ${ }_{2} \mathrm{SO}_{4}$ on system response. Surface was found to be more concave in this case which depicted quadratic effect of $\mathrm{pH}$ on lipid production. $\mathrm{pH}$ was found to have a positive effect on the system response and required to be maintained at high values of the same. Similar result has been reported Gong et al. (2013) where increase in lipid production has been observed by increment in initial $\mathrm{pH}$. Considering both factors, maximum lipid production of $1.5424 \mathrm{~g}$ was obtained with $\mathrm{pH}$ and $\left(\mathrm{NH}_{4}\right)_{2} \mathrm{SO}_{4}$ values of 6 and $0.5 \mathrm{~g}$ respectively. An effect of $\mathrm{KH}_{2} \mathrm{PO}_{4}$ and temperature on lipid production at fixed values of rest variables was depicted in Figure 4. It demonstrated that $\mathrm{KH}_{2} \mathrm{PO}_{4}$ and temperature at their maximum values of $0.70 \mathrm{~g}$ and $38^{\circ} \mathrm{C}$ led to maximum lipid production of $1.5253 \mathrm{~g}$ whereas temperature at its lowest value of $30^{\circ} \mathrm{C}$ with same $\mathrm{KH}_{2} \mathrm{PO}_{4}$ conc. yielded a slightly lesser value on lipid content. So the response was more sensitive to changes in $\mathrm{KH}_{2} \mathrm{PO}_{4}$ concentration compared to temperature when the other variables were held constant. This fact was also supported by Pareto chart diagram (Figure 1), where $\mathrm{KH}_{2} \mathrm{PO}_{4}$ was observed to be most significant variable amongst the selected ones. Based on the predicted model, an optimization study was carried out for maximizing lipid yield. Maximum lipid content predicted by the model was found to be $2.12 \mathrm{~g}$ with $30 \mathrm{~g} \mathrm{Xy-}$ lose, $0.5 \mathrm{~g}\left(\mathrm{NH}_{4}\right)_{2} \mathrm{SO}_{4}, 0.375 \mathrm{~g} \mathrm{KH}_{2} \mathrm{PO}_{4}, 0.35 \mathrm{~g}$ Yeast extract, $\mathrm{pH}$ value of 6.0 and fermentation temperature of $38^{\circ} \mathrm{C}$. The data was further validated in a shake flask where the experiment was carried out under optimized condition.

\section{Validation of computational model}

Validation of predicted computational model was tested in shake flask with optimized conditions yielding $2.1199 \mathrm{~g}$ of lipid which is almost identical to the model predicted value (Figure 5). This validated the accuracy of predicted model and confirmation of an optimum point within the system for achieving targeted lipid yield.

\section{Qualitative assessment of lipid}

Apart from almost uniform distribution of lower carbon fatty acids $\left(\leq \mathrm{C}_{6}\right.$ to $\geq \mathrm{C}_{14}$ ) qualitative distribution of $\mathrm{C}_{16: 0}$ (palmitic acid), $\mathrm{C}_{16: 1}$ (palmitoleic acid), $\mathrm{C}_{18: 0}$ (stearic acid), $\mathrm{C}_{18: 1}$ (oleic acid), $\mathrm{C}_{18: 2}$ (linoleic acid) and $\mathrm{C}_{18: 3}$ (linolenic acid) were targeted through GC/MS. With increase in $\mathrm{C} / \mathrm{N}$ ratio, lipid yield significantly increased. Irrespective of temperature, lipid yields were almost similar for $\mathrm{C} / \mathrm{N}$ ratio of 25 . With increase in temperature beyond $30^{\circ} \mathrm{C}, \mathrm{C}_{18: 2}$ (linoleic acid) was produced and $\mathrm{C}_{18: 3}$ (linolenic acid) was not. In case of lower temperature $\left(30^{\circ} \mathrm{C}\right), \mathrm{C}_{18: 2}$ (linoleic acid) was not present while $\mathrm{C}_{18: 3}$ (linolenic acid) productions were observed. Almost in all 13 cases palmitoleic acid $\left(\mathrm{C}_{16: 1}\right)$ has been found to be produced which is a rare fatty acid found in microbial source. Conversion of lipid with respect to consumed carbon $\left(C_{5}\right.$ sugar) can be represented as fat coefficient (\%) which was found to be nearly similar in all cases (Table 4) ranging from 6 to 8 . Fat coefficient came out to be $7.06 \%$ for flask with model validation experiment which also fell within the range. It clarified the capacity of conversion of sugar into lipid by IIP-33.

\section{Conclusion}

In this paper we have targeted to optimize maximum lipid yield on weight basis with different physical parameters and nutrient combinations as per software predicted variants. Pentose rich broth derived from lignocellulosic biomass was selected as carbon source for lipid production by IIP-33. Optimized condition was verified in shake 


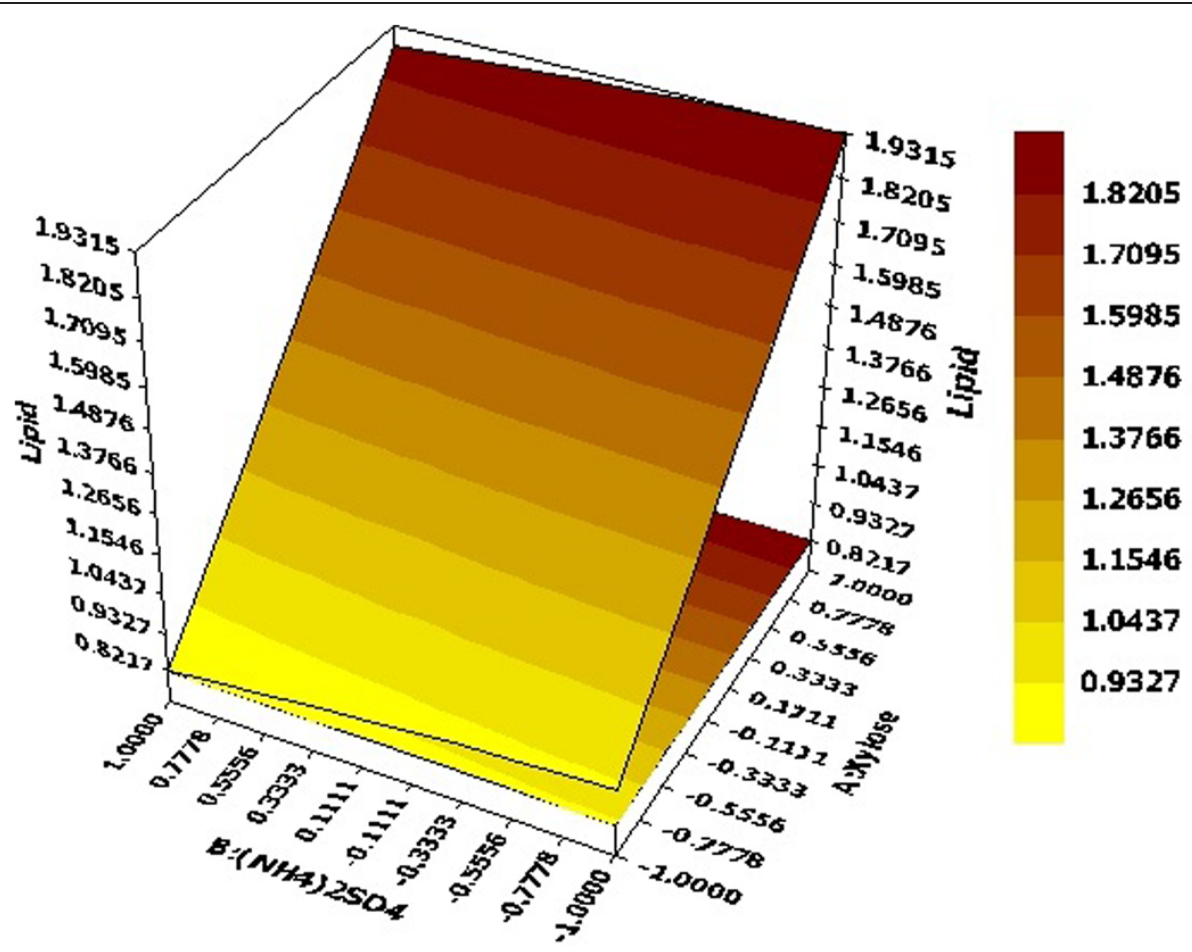

Figure 2 Effects of Xylose and $\left(\mathrm{NH}_{4}\right)_{2} \mathrm{SO}_{4}$ conc. on lipid production; Hold values $\mathrm{C}=0\left(\mathrm{KH}_{2} \mathrm{PO}_{4}=0.525 \mathrm{~g}\right), \mathrm{D}=0$ (Yeast extract $\left.=0.5 \mathrm{~g}\right)$, $\mathrm{E}=0(\mathrm{pH}=5), \mathrm{F}=0\left(\right.$ Temperature $\left.=34^{\circ} \mathrm{C}\right)$.

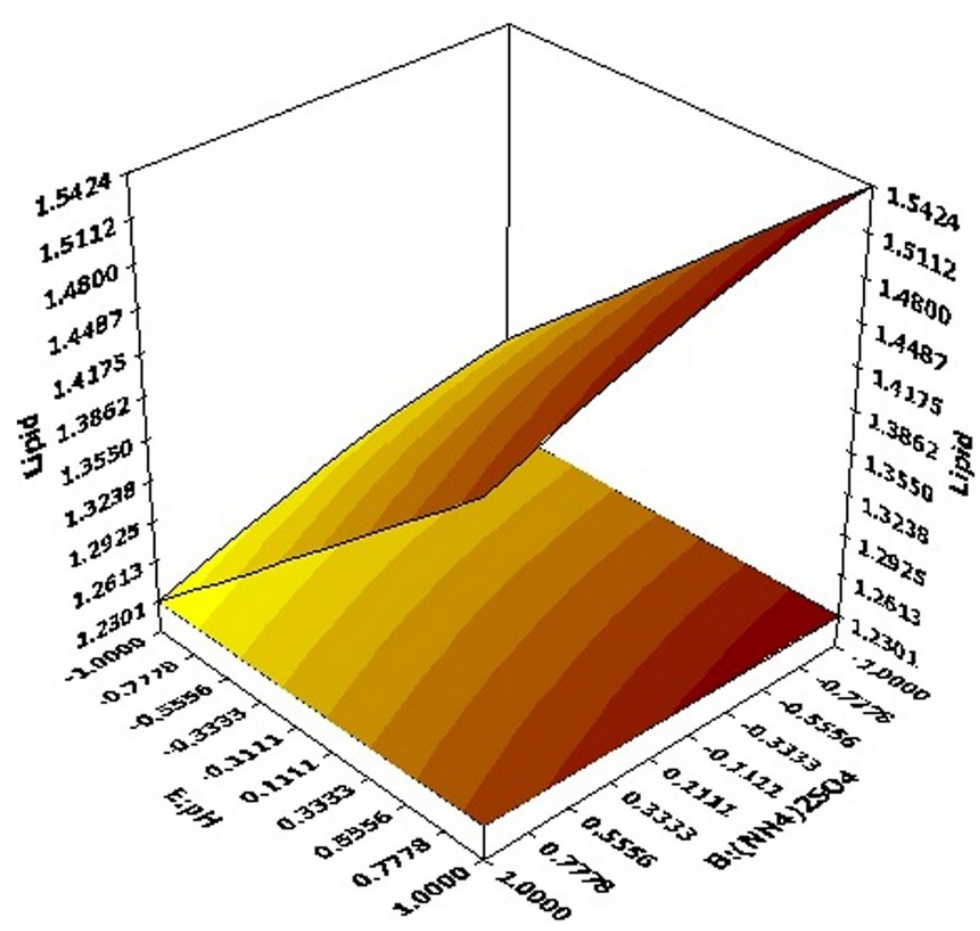

1.5112

1.4800

1.4487

$\mathbf{1 . 4 1 7 5}$

1.3862

1.3550

1.3238

1.2925

1.2613

Figure 3 Effects of $\left(\mathrm{NH}_{4}\right)_{2} \mathrm{SO}_{4}$ conc. and $\mathrm{pH}$ on lipid production; Hold values $\mathrm{A}=0$ (Xylose conc. $\left.=20 \mathrm{~g}\right), \mathrm{C}=0\left(\mathrm{KH}_{2} \mathrm{PO}=0.525 \mathrm{~g}\right.$ ), D =0 (Yeast extract $=0.5 \mathrm{~g}), \mathrm{F}=0\left(\right.$ Temperature $\left.=34^{\circ} \mathrm{C}\right)$. 


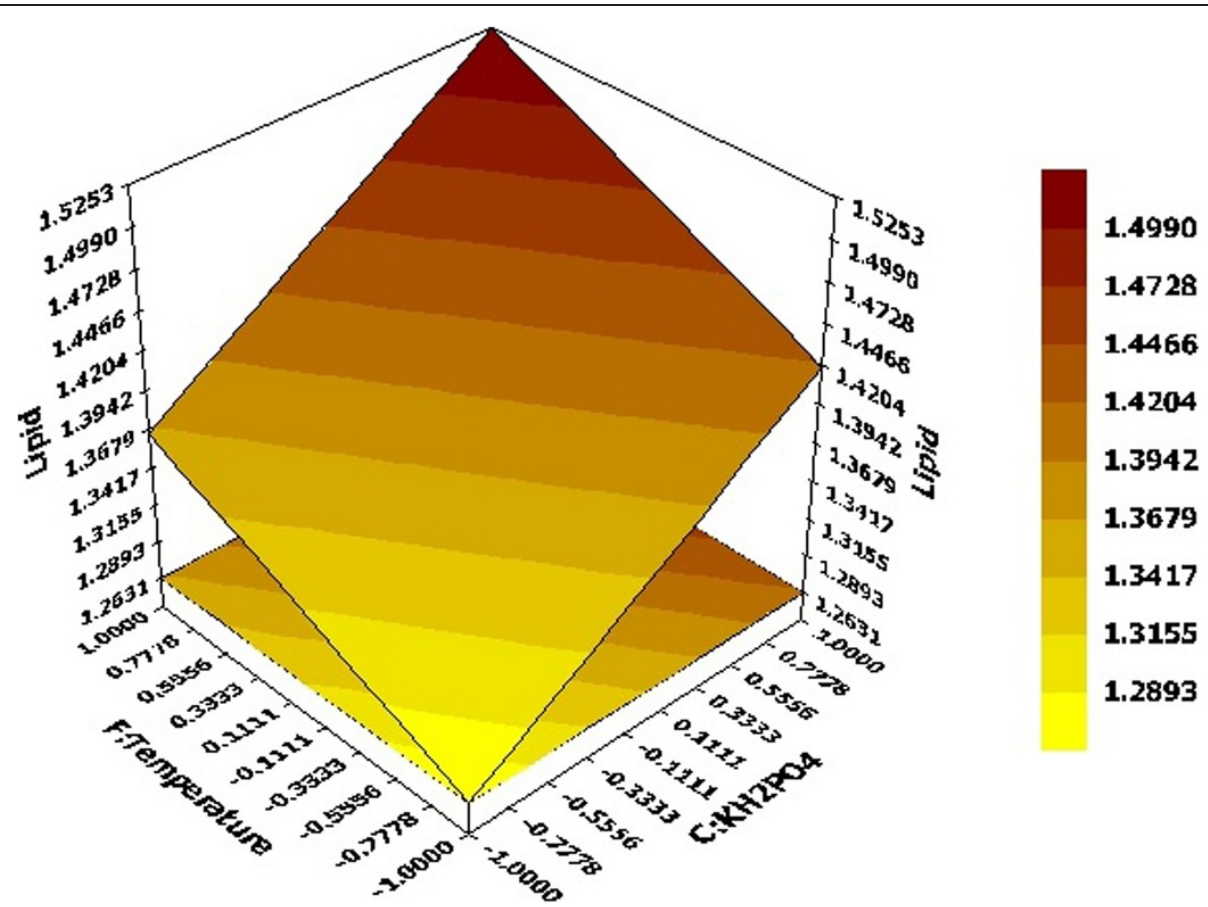

Figure 4 Effects of $\mathrm{KH}_{2} \mathrm{PO}_{4}$ and Temperature on lipid production; Hold values $\mathrm{A}=0$ (Xylose $=20 \mathrm{~g}$ ), $\mathrm{D}=0$ (Yeast extract $=0.5 \mathrm{~g}$ ), $\mathrm{E}=0$ $(\mathrm{pH}=5), \mathrm{B}=0\left(\left(\mathrm{NH}_{4}\right)_{2} \mathrm{SO}_{4}=0.75 \mathrm{~g}\right)$.

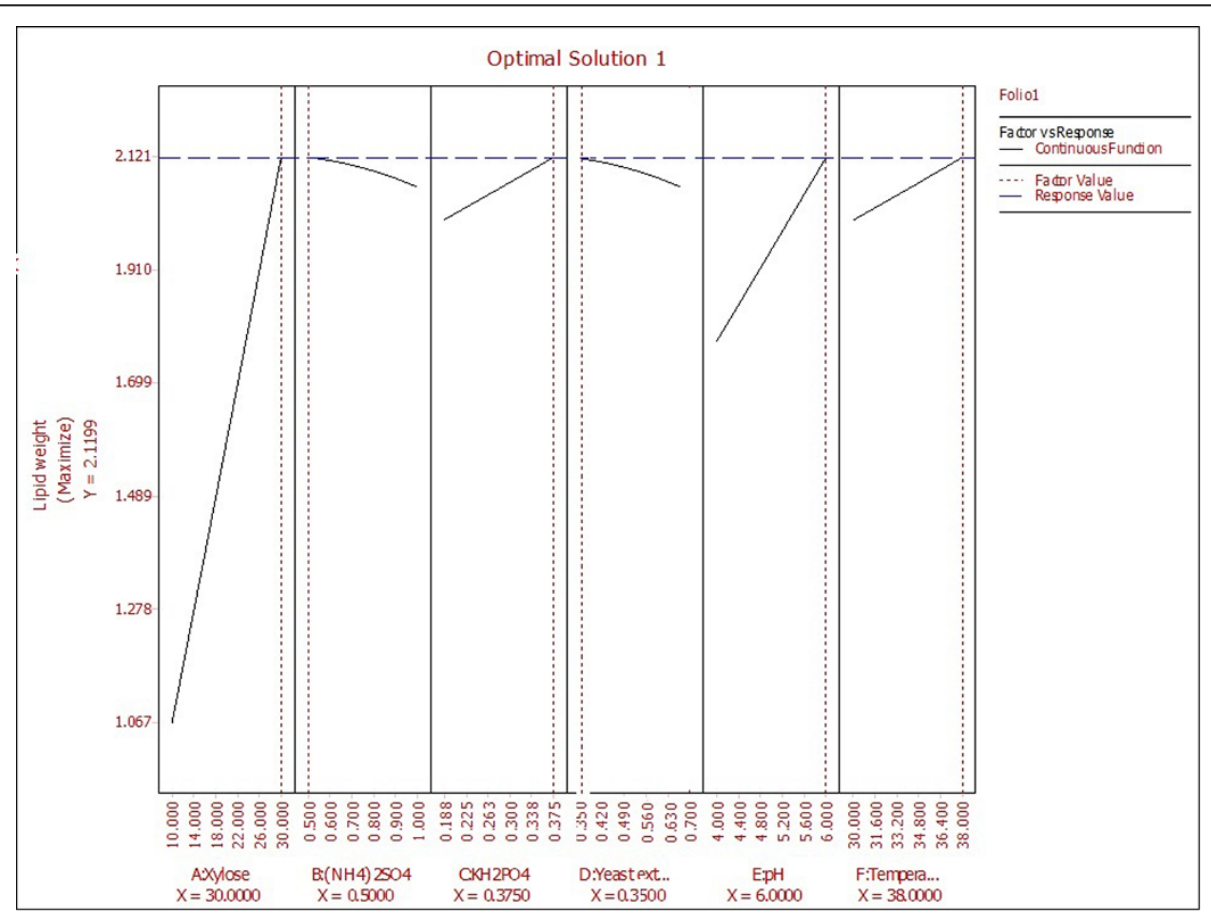

Figure 5 Optimization conditions for maximizing lipid yield predicted by Reliasoft DOE. 
flask which was almost identical to the model predicted value. In case of total lipid, fat coefficient are reported nearly 20 to $22 \%$ for oleaginous yeast. We have only considered non polar lipid/fatty acid fractions which would be suitable for hydro-treatment for conversion to hydrocarbon. $\mathrm{CHCl}_{3} / \mathrm{CH}_{3} \mathrm{OH}$ extracted total lipid which included polar lipids including phospholipids as well as glycolipids which might lead to catalyst poisoning during selective deoxygenation. n-Haxane selectively extracted non-polar fractions from $\mathrm{CHCl}_{3} / \mathrm{CH}_{3} \mathrm{OH}$ extractives which lowered the fat coefficients by $\sim 50 \%$, but optimization on this basis would definitely help to further scale up lipid production from cheap biomass source like sugarcane bagasse.

\section{Competing interests}

The authors declare that they have no competing interests.

\section{Authors' contributions}

DDG and SB designed and conducted research (project conception, research planning, study oversight, hands-on conduct of the experiments and data collection) and performed statistical analysis along with manuscript drafting; SK and DG had primary responsibility of data representation and final shaping of the manuscript; DA and SB carried out cell culture maintenance; JA and DG carried out acid hydrolysis of bagasse, lipid fermentation and lipid extraction; PK and SKS carried out GC/MS analyses; DG supervised overall work and participated in result interpretation with SK, DDG and DKA; DG is also the corresponding author. All authors read and approved the final manuscript.

\section{Acknowledgement}

Authors are grateful to Director, CSIR-Indian Institute of Petroleum for providing necessary facilities to complete this work and constant encouragement. Authors are also grateful to CSIR for necessary funding through grant no. CSC-0116.

\section{Author details}

'Biofuels Division, CSIR-Indian Institute of Petroleum, Mohkampur, Dehradun 248 005, Uttarakhand, India. ${ }^{2}$ Analytical Sciences Division, CSIR-Indian Institute of Petroleum, Mohkampur, Dehradun 248 005, Uttarakhand, India.

Received: 30 September 2014 Accepted: 12 November 2014 Published: 25 November 2014

\section{References}

Amaretti A, Raimondi S, Sala M, Roncaglia L, Lucia MD, Leonardi A, Rossi M (2010) Production of single cell oils by the cold adapted oleaginous yeast Rhodotorula glacialis AS 4.7: effects of the growth temperature and C:N ratio. Chem Eng Trans 20:109-114

Botham PA, Ratledge C (1979) A biochemical explanation for lipid accumulation in Candida 107 and other oleaginous microorganisms. J Gen Microbiol 114:361-375

Box GEP, Behnken DW (1960) Some new three level designs for the study of quantitative variables. Technometrics 2:455-475

Braunwald T, Schwemmlein L, Graeff-Hönninger S, French WT, Hernandez R, Holmes WE, Claupein W (2013) Effect of different C/N ratios on carotenoid and lipid production by Rhodotorula glutinis. Appl Microbiol Biotechnol 97:6581-6588

Chandra V (1997) Studies on yeast lipids used as lubricant additives PhD Thesis. University of Roorkee (presently IIT Roorkee), Roorkee, India

da Silva TL, Gouveia L, Reis A (2014) Integrated microbial process for biofuels and high value added products: the way to improve the cost effectiveness of biofuel production. Appl Microbiol Biotechnol 98:1043-1053

Dasgupta D, Suman SK, Pandey D, Ghosh D, Khan R, Agrawal D, Jain RK, Vadde VT, Adhikari DK (2013) Design and optimization of ethanol production from bagasse pith hydrolysate by a thermotolerant yeast Kluyveromyces sp. IIPE453 using response surface methodology. SpringerPlus 2:159-168
Flores CL, Rodrigue ZC, Petit T, Gancedo C (2000) Carbohydrate and energy-yielding metabolism in non-conventional yeasts. FEMS Microbiol Rev 24:507-529

Gong Z, Shen H, Wang Q, Yang X, Xie H, Zhao ZK (2013) Efficient conversion of biomass into lipids by using the simultaneous saccharification and enhanced lipid production process. Biotechnol Biofuels 6:36-46

Hamid S, Khan A (1991) Temperature effects in the biosynthesis of fatty acids of C. utilis. Pak J Sci Ind Res 34:293-295

Holdsworth JE, Ratledge C (1988) Lipid turnover in oleaginous yeasts. J Gen Microbiol 134:339-346

Jain RK, Thakur W, Pandey D, Adhikari DK, Dixit AK, Mathur RM (2011) Bioethanol from bagasse pith a lignocellulosic waste biomass from paper/sugar industry. IPPTA 23:169-173

Janßen HJ, Ibrahim MHA, Bröker D, Steinbüchel A (2013) Optimization of macroelement concentrations, $\mathrm{pH}$ and osmolarity for triacylglycerol accumulation in Rhodococcus opacus strain PD630. AMB Exp 3:38-45

Li Q, Du W, Liu D (2008) Perspectives of microbial oils for biodiesel production. Appl Microbiol Biotechnol 80:749-756

Plackett RL, Burman JP (1946) The design of optimum multifactorial experiments. Biometrika 33:2147-2157

Ratledge C (2004) Fatty acid biosynthesis in microorganisms being used for single cell oil production. Biochimie 86:807-815

Ratledge C, Wynn JP (2002) The biochemistry and molecular biology of lipid accumulation in oleaginous microorganisms. Adv Appl Microbiol 51:1-51

Saxena V, Sharma CD, Bhagat SD, Saini VS, Adhikari DK (1998) Lipid and fatty acid biosynthesis by Rhodotorula minuta. JAOCS 75:501-505

Verma D, Kumar R, Rana BS, Sinha AK (2011) Aviation fuel production from lipids by a single-step route using hierarchical mesoporous zeolites. Energy Environ Sci 4:1667-1671

Wackett LP (2008) Microbial-based motor fuels: science and technology. Microbial Biotechnology. J Microbial Biotechnol 1:211-225

Wiebe MG, Koivuranta K, Penttilä M, Ruohonen L (2012) Lipid production in batch and fed-batch cultures of Rhodosporidium toruloides from 5 and 6 carbon carbohydrates. BMC Biotechnol 12:26-35

doi:10.1186/2193-1801-3-691

Cite this article as: Bandhu et al:: Statistical design and optimization of single cell oil production from sugarcane bagasse hydrolysate by an oleaginous yeast Rhodotorula sp. IIP-33 using response surface methodology. SpringerPlus 2014 3:691.

\section{Submit your manuscript to a SpringerOpen ${ }^{\odot}$ journal and benefit from:}

- Convenient online submission

- Rigorous peer review

- Immediate publication on acceptance

- Open access: articles freely available online

- High visibility within the field

- Retaining the copyright to your article

Submit your next manuscript at $\gg$ springeropen.com 